approach channels to Gothenburg that the current speed and direction vary widely in vertical as well as in horizontal directions. The current vector can often describe a spiral curve from the surface to the bottom, sometimes with a difference of $180^{\circ}$ in 20 metres depth difference, and quite often there is also a set to one side forward and the opposite aft. In shallow waters the interaction between the ship and the seabed will usually play havoc with the motion of the watermass at the transducer of a log. Using the STw in simulators will be fine of course, as most simulators will not have the capacity to simulate turbulent water flow. In actual operation, however, far greater values are at stake and greater caution must be exercised.

The discussion also gives me an uneasy impression of a contravention of the basic rule that one should never enter into a close quarter situation even with the aid of ARPA or basic manual plotting. In narrow channels, this cannot always be avoided, but then other procedures have to be used. As history has shown, there are too many navigators already that have got into trouble by asking more from their instruments than the instrument in question can possibly manage.

It is said that a collision at sea can ruin your whole day and I do believe, although so far lacking personal experience of either, that the same applies to a grounding.

\title{
Air Marshal Sir (Charles) Edward Chilton, KBE, CB, FRIN
}

The death of Air Marshal Sir Edward Chilton on 4 August 1992 aged 85 has deprived his survivors of a staunch friend of great integrity and an adviser of immense wisdom and experience. Certainly his loss will be felt by all those Members of the Institute and by innumerable others who had the privilege of his confidence.

His brilliant Service career, which culminated as Commander in Chief of Coastal Command in 1959, has been publicly well documented in The Times and Daily Telegraph, though somewhat reserved references were made of his dogged defence of the dominant role played by the Royal Air Force in all the WW2 maritime operations. Several very high-powered and arguably dangerous attempts were made during that war and afterwards by the Admiralty to take over the Royal Air Force maritime elements, and these efforts continued, surprisingly, until quite recently; but they always came up against the passionate and well-informed vigilance of this dedicated protagonist and have all so far fortunately been fended off.

As a leading participant in the air Battle of the Atlantic, 'Chillie' commanded RAF Chivenor and its two deadly Leigh-light Wellington squadrons in 1943. In 1944, as Group Captain Operations of 19 Group, Mount Batten, working closely with the Royal Navy, he was responsible for implementing Operation Cork which began in May, a month before D-Day and continued until all threat, especially from the Brittany-based U-Boat fleet, had been eliminated.

This enormous air operation required the intensive employment of no fewer than 60 squadrons, mostly land-based and of varying nationalities, types and capabilities. The task was to sweep a sea area of $190000 \mathrm{sq}$ miles lying westwards from the cross-Channel invasion routes to an arc 500 miles into the Atlantic from the Scillies and bounded by Cape Finisterre in Spain and Mizen Head in SW Ireland. Every inch of this vast ocean had to be covered by Asv-equipped aircraft every half an hour, day and night, in all weathers, and to continue until further notice. When necessary, the maritime resources of RAF Gibraltar were called in to help, being able to tie into the precise navigational 
co-ordinates of the planned sweeps thanks to the SW GEE chain and to Consol (courtesy of the enemy). In concept the plan, devised at Coastal Command Headquarters, Northwood, resembled a giant bus time-table, but it needed a master hand at the control centre.

The devastation wreaked upon the U-boats was of immeasurable value to Admiral Ramsey, the Naval C-in-C South Western Approaches at Plymouth; Operation Overlord proceeded almost scatheless at the grave expense of the U-boats. To everyone concerned with the maritime protection of the invasion fleet, it was a great reassurance to know that an officer with such impeccable air navigational expertise had his finger on the trigger. Many of 'Chillie"'s colleagues basked in the reflected glory of the success of his astute acumen and he himself was duly appointed a CBE in 1945.

Commissioned as a pilot in 1926 and trained as a navigation specialist in $193 \mathrm{I}$, he was certificated an Air Master Navigator in 1937. As a pilot, 'Chillie' was also amphibious, being equally at home in flying boats as in land aircraft. He recently wrote of his exploits during a pre-war flying boat cruise of the Baltic.

In 1947 he worked on the staff of the CAS as Deputy Director of Navigation where, as part of his extra-mural activities, he was able to join a group of naval, air and sailing enthusiasts and scientists who met every month at the Royal Geographical Society to formulate the aims and plan the organization of an institute of navigation, which in due course received Royal patronage and blossomed into our present highly respected Royal Institute.

During this Air Ministry posting, until ${ }_{1949}$, he set about preparing the specification for advanced navigational systems, and in particular for Doppler, in conjunction with scientists at TRE. In 1949 he was elected Fellow for his many contributions to air navigation, not to mention his effective fostering of its Service and civilian organization. Vice-President 1949-51, 1959-61 and 1963-5, he became a Life Member in 1972. He continued to maintain a lively interest in the unfolding development of air navigation systems for the rest of his life, which of course had spanned almost its entire history.

A little-publicized but much-cherished feather in his cap was the creation of the RAF Aries Association, which holds annual symposia and commemorates the famous Lancaster Aries that blazed the Arctic trails from the Empire Air Navigation School at RAF Shawbury in April 1945 across the North Pole and the North Magnetic Pole and made the first truly circumferential transit of the globe. Members of Aries were originally exclusively RAF-trained navigation specialists from all over the world, but in the course of time entry has been widened to embrace their modern Service equivalents. "Chillie "s personal flair and ardent support has left many such initiatives as lasting and lively mementoes of his passing.

'Chillie', as he always signed himself, was a great raconteur, often the life and soul of a Service party. His slight build and diffident manner were deceptively bland and he was able to throw away a line with devastating effect. His brain remained rapier-sharp to the very end and his exceptional powers of recall made him a veritable mine of accurate information about the Royal Air Force. Indeed, in his later years he blossomed as an air historian of considerable repute and compulsively entered the fray whenever he found that the record needed to be straightened in some vital detail.

A great stickler not only for truth but also for perfection, his sense of humour always came to the rescue when he saw that, try as he might, he could not command the tides. He always set the highest targets for himself and strove to carry others along with him, but far from being a martinet or rank-conscious, his sparkling good nature made him a most endearing companion in good times and in bad. He was a very brave, resourceful, highly considerate and intelligent officer whose counsel will be gravely missed.

Group Captain F. C. Richardson 